\title{
MENEMUKAN UNIVERSALITAS PESAN ALQURAN SEBAGAI KENISCAYAAN DALAM PENAFSIRAN MULTI-INTERDISIPLINER
}

\author{
Wardani \\ UIN Antasari Banjarmasin \\ mwardanibjm@gmail.com \\ Wardatun Nadhiroh \\ UIN Antasari Banjarmasin \\ wnadhiroh@uin-antasari.ac.id
}

\begin{abstract}
This article aims to lay a philosophical foundation on the universality of the message of the Qur'an as a necessity in a multiinterdisciplinary approach to interpret the Qur'an. The study departs from the thoughts of Qur'anic scholars from the classical to the contemporary period as set out in their works. The "universality" here means two senses: first, compatibility of the message, owing to its universal and perennial ethical contents, to be applied across boundaries of time and space; second, various aspects of contents of the Qur'an, such as theological, legal, ethical, and scientific issues. This article also suggests methods in exploring the universality of the Qur'anic doctrines and gives one example of its application, especially in understanding Quranic values in its doctrine of warfare. The authors conclude that an integrative approach to the Qur'an is needed to be accompanied by an awareness of the universality of the message of the Qur'an which lies in the spirit of ethical principles and the need for meaning in a broader spectrum in the modern era. Neglecting its universal message will cause interpretations losing this spirit, such as classical Moslem interpreters' understanding on jihäd-verses by insisting that the jihäd as warfare is a permanent obligation upon Moslems. The falsehood of the interpretation is due to neglecting the ethical principle i.e. humanity behind the law of reciprocity that underlies particular verses on warfare.
\end{abstract}

Keywords: universality, particularity, ușil, furu', interpretation

\begin{abstract}
Abstrak: Artikel ini bertujuan untuk meletakkan landasan filosofis terhadap konsep universalitas pesan Alquran sebagai sebuah kebutuhan dalam pendekatan multi-interdisipliner untuk menafsirkan Alquran. Penelitian ini berangkat dari pemikiran para sarjana Alquran dari periode klasik ke periode kontemporer sebagaimana tercantum dalam karya-karya mereka. "Universalitas" di sini memiliki dua pengertian: pertama, kesesuaian pesan, karena isinya yang universal dan abadi, untuk diterapkan melintasi batas waktu dan ruang; kedua, berbagai aspek isi Alquran, seperti masalah teologis, hukum, etika, dan ilmiah. Artikel ini juga menawarkan metode dalam mengeksplorasi universalitas doktrin Alquran dan memberikan satu contoh penerapannya, terutama dalam memahami nilai-nilai Alquran, khususnya
\end{abstract}


dalam doktrin perang. Para penulis menyimpulkan bahwa pendekatan integratif terhadap Alquran diperlukan untuk disertai dengan kesadaran akan universalitas pesan Alquran yang terletak pada semangat prinsip-prinsip etis dan kebutuhan akan makna dalam spektrum yang lebih luas. Mengabaikan pesan universal akan menyebabkan penafsiran kehilangan semangat ini, seperti pemahaman penafsir Muslim klasik tentang ayat-ayat jihad dengan menegaskan bahwa jihad perang adalah kewajiban permanen bagi umat Islam. Kekeliruan interpretasi, dengan demikian, adalah karena sikap abai terhadap prinsip etika, misalnya, prinsip kemanusiaan yang inheren di balik hukum timbal balik yang mendasari ayat-ayat khusus tentang perang.

Keywords: universalitas, partikularitas, $u s \bar{u}$, fur $\bar{u}$, penafsiran.

\section{Pendahuluan}

Ibn 'Abbās (w. 68/688), sang bapak tafsìr (Abü al-Tafsìr), pernah berpendapat bahwa ayat (QS. Áli 'Imrān: 110)1 yang menjelaskan tentang kaum muslimin sebagai "umat terbaik" dengan beban tugas amr bi al-ma'rü dan naby 'an al-munkar lebih relevan dengan konteks kehidupan yang ideal pada masyarakat Madinah yang dibangun oleh Nabi Muhammad. ${ }^{2}$ Tentu saja, Ibn 'Abbās, karena bertolak dari riwayat dan melihat sejarah dengan pendekatan idealis, melihat ayat ini lebih relevan dengan sejarah masa lampau. Dengan begitu, pesan universal ayat menjadi tidak "hidup dan membumi". Ibn 'Abbās tampak melihat keistimewaan umat Islam tersebut sebagai hal yang dianugerahkan (given), bukan sebagai sesuatu yang harus diperjuangkan secara konstan. Padahal, kalau kita mempertimbangkan ciri-ciri penting umat terbaik tersebut diungkapkan dengan kata kerja ( $i^{i}$ ') yang mengandung konotasi gerak dan perubahan (tajaddud) dalam bentuk mudäri (yang menunjukkan keadaan sekarang dan akan datang), anugerah kepada umat Islam sebagai umat terbaik adalah sesuatu yang potensial dan harus diperjuangkan. Di sisi lain, anugerah tersebut adalah sesuatu yang bisa hilang.

Jika penafsiran Ibn 'Abbās kembali ke sejarah masa lalu, al-Sayyid 'Abd al-Hādi dalam karyanya, Hädhibi> Ummatukum, bahkan, mempersempit sasaran ayat tersebut hanya kepada superioritas bangsa

\footnotetext{
1 Ayat tersebut berbunyi: Kamu adalah umat yang terbaik yang dilahirkan untuk manusia, menyuruh kepada yang makruf, dan mencegah dari yang munkar, dan beriman kepada Allah. Sekiranya, Ahli Kitab beriman, tentulah itu lebih baik bagi mereka; di antara mereka ada yang beriman, dan kebanyakan mereka adalah orangorang yang fasik.

2 Ismāīl b. 'Umar b. Kathir, Tafsìr al-Qur'ān al-Ažìm, vol. 1 (Beirut: Dār al-Fikr, 1986), 392-397.
} 
Arab. ${ }^{3}$ Berbeda dengan Sayyid 'Abd al-Hādi yang menekankan Arabisme, penafsiran Ibn 'Abbās sesuai dengan penafsiran 'Umar b. al-Khațtāb, meski tampak menganut idealisasi sejarah Islam masa awal, menolak cakupan ayat tersebut hanya mengidealisasikan masa lalu, melainkan juga memiliki pesan moral yang masih berlaku hingga kini.

Ini hanyalah salah satu contoh penafsiran ayat Alquran, di mana para penafsir berangkat dari titik-tolak berbeda sampai pada kesimpulan berbeda berkaitan dengan pesan temporal atau universal yang dikandungnya. Persoalan universalitas pesan-pesan Alquran dari klasik hingga sekarang tetap menjadi magnet yang menarik para pengkaji Alquran untuk mengkajinya. Debat tentang patokan "al-ibrah bi 'umüm al-lafd?" atau "al-ibrah bi khusüs al-sabab", misalnya, disikapi berbeda oleh para pengkaji Alquran. Mayoritas ulama memilih pilihan pertama, ${ }^{4}$ sementara sebagian pakar, seperti Nașr Hạmid Abū Zayd dan M. Quraish Shihab menggarisbawahi pentingnya konteks spesifik latar belakang turun ayat menjadi titik-tolak dalam memahami ayat. Abū Zayd dengan bertolak dari fakta bahwa naș turun dari realitas dan diproyeksikan ke realitas, menekankan penting "sebab spesifik" dan menggugat "dualisme" patokan itu. ${ }^{5}$ M. Quraish Shihab menekankan fungsi "sebab spesifik" tersebut bagi pengembangan tafsir, karena deskripsi peristiwa secara lengkap (peristiwa, pelaku, dan waktu) diperlukan dalam mendudukkan ayat pada konteks sejarah sesungguhnya. ${ }^{6}$

Persoalan universalitas dan partikularitas pesan-pesan Alquran terus menggelayut dalam perdebatan para pakar. Sebagian mengutamakan sisi universalitas, sedangkan sebagian lain menegaskan sisi partikularitas. Apa sesungguhnya universalitas pesan Alquran tersebut? Bagaimana kita bisa menarik pesan universalitas dari ayat Alquran, baik universalitas dalam pengertian "keberlakuan" pesan ayat secara luas karena kandungan nilai-nilai permanennya maupun

3 Al-Sayyid 'Abd al-Hāèi, Hādhibi> Ummatukum (Kairo: Dār al-Fikr al-'Arabī, 1992), 21-25.

${ }^{4}$ Lihat, misalnya, Muhammad Sălim Abū 'Ạ̄s, Asbāb al-Nuzūi: Tạ̣dìd Mafāhìm wa Radd Shububāt (Kairo: Dār al-Bașāir, 1996), 61-87; 'Abd al-Raḥmān al-Sa'di, AlQawa' id al-Hisāanli Tafsìr al-Qur'ān (t.tp.: Dār Ibn al-Jawzi, t.th), 18-19, 8-9.

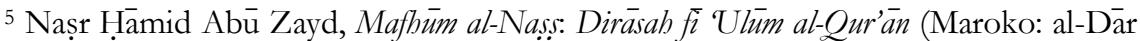
al-Baydàa, al-Markaz al-Ṭaqāî al-'Arabì, 2005), 102-108.

${ }^{6}$ Lihat M. Quraish Shihab, Membumikan al-Qur'an: Fungsi dan Peran Wabyu dalam Kehidupan Masyarakat (Bandung: Mizan, 1995), 89-90. 
"keserba-mencakupan" kandungan ayat terhadap aspek-aspek doktrin dan kehidupan manusia?

\section{Universalitas, Partikularitas, dan Nilai-nilai Alquran: Perbincangan Awal}

"Universalitas" di sini dipahami sebagai keberlakuan pesan ayat Alquran dalam lintas ruang-waktu (salähiyat al-nașs li kull zamān wa makān), tidak terbatas pada konteks masyarakat Arab (kecuali ayat-ayat tertentu yang memang terkait dengan lokalitas), melainkan semua lapisan Muslim di seluruh dunia. Ayat dimaksud bisa dalam pengertian ayat yang kandungannya memang universal (kulliyah), karena mencakup seluruh Muslim, atau "ayat pokok", yaitu ayat yang memuat aturan yang lebih universal (norma, kaidah) dibandingkan "ayat ranting" yang memuat aturan spesifik. Bahkan, melalui nilainilainya (values, qiyam), seperti keadilan, pesan Alquran tersebut diidealisasikan menjadi pesan kemanusiaan. "Universalitas" tersebut juga bisa bermakna kandungan ayat Alquran yang banyak mencakup (shumütiyah) multi-aspek, baik berkaitan keyakinan, ibadah, moral, sosial-kemasyarakatan, hingga "isyarat ilmiah" dari perspektif ilmu alam seperti fisika maupun ilmu sosial seperti sosiologi. Berkaitan dengan hal tersebut, Fazlur Rahman menyebut "Alquran adalah dokumen yang ditujukan kepada manusia, karena ia menyebut dirinya 'petunjuk bagi manusia' (budā li al-nās) ".?

Universalitas tidak menafikan pentingnya lokalitas. ${ }^{8}$ Universalitas hanya menolak arabisme Islam sebagai asumsi yang membatasi pesan Islam hanya di Jazirah Arab, atau paham komunalisme yang membatasi Islam pada komunitas tertentu. ${ }^{9}$ Ini sealur dengan apa yang

\footnotetext{
7 "The Qur'an is a document that is squarely aimed at man; indeed, it calls itself "guidance for mankind (budā li al-nās [2:185] and numerous equivalents elsewhere)". Fazlur Rahman, Major Themes of the Qur'an (Kuala Lumpur: Islamic Book Trust, 1989), 1.

8 Perlu dicatat di sini bahwa "universalitas" bukanlah "universalisme", seperti dalam ungkapan "universalisme Islam", sebagaimana dikhawatirkan Ahmad Baso, sebagai jargon yang sebenarnya dimaksudkan sebagai kolonialisme, karena dengan menyebutkan Islam mencakup semua aspek, itu akan menyingkirkan "lokalitas Islam”. Baso melihat perpindahan IAIN ke UIN adalah bagian dari turunan ide universalisme itu. Ahmad Baso, Islam Pasca-Kolonial (Bandung: Mizan, 2005), 23-27. Universalitas dimaksud adalah keberlakuan pesan-pesan Alquran bagi Muslim, bahkan semua manusia, karena Alquran sendiri menyebut dirnya sebagai "petunjuk bagi manusia" (budā li al-nās).

9 Lihat Chandra Muzaffar, "Universalism in Islam," dalam Liberal Islam: A Sourcebook, ed. Charles Kurzman (Oxford: Oxford University Press, 1998), 155-156
} 
dikemukakan Abdullahi Ahmed An-Naim di awal bukunya yang kontroversial, Toward an Islamic Reformation, dengan mengajukan tesis bahwa interpretasi dan praktik semua agama, termasuk Islam, banyak dipengaruhi oleh kondisi sosiologis, ekonomis, dan politis masyarakat tertentu. Hal ini juga berlaku pada syariat, bahkan pada agama tertentu terdapat batas keragamaan dan kekhususan. Tesis ini dibangun atas dasar asumsi bahwa terdapat aspek-aspek universal dalam Islam dan Syariat, tanpa bermaksud menolak adanya keragaman pada tingkat sosiologis, dan keragamaan lainnya. Aspek universal inilah yang menjadi titik-tolak kemungkinan melakukan reformasi Islam. ${ }^{10}$ Aspek universal tersebut tentu terkait dengan nilai-nilai etis yang mendasari ajaran-ajaran Islam, seperti keadilan.

Dalam konteks universalitas nilai-nilai Alquran, harus diakui bahwa meski semua isi ajaran Alquran berasal dari Tuhan yang sama, yaitu Allah, tidak semua ayat Alquran sama levelnya ketika berbicara tentang segala sesuatu; terkadang Alquran menjelaskan hukum (teologis, juridis, maupun moral) sesuatu secara satu persatu, kasus per-kasus, secara partikular, juг, $\bar{i}$, atau terkadang Alquran menjelaskannya dalam bentuk suatu patokan, kaidah, atau ketentuan yang berisi nilai yang cakupannya universal, kulli, bisa "menaungi" kasus-kasus spesifik di bawah "payungnya".

Wacana universalitas Alquran tidaklah aneh dan berlebihan. Sebagai langkah awal, Jalāl al-Dīn al-Suyūtị (w. $911 \mathrm{H}$ ), salah seorang perintis 'ulum al-Qur'an, menulis dalam karyanya, Al-Tạ̣bir fi $\bar{i} \mathrm{Tlm}$ alTafsir ${ }^{11}$ (karya yang dimaksudkan sebagai pengembangan tema-tema kajian 'ulum al-Qur'ān dengan berpatokan kepada Mawäqi' al-'Ulüm karya al-Bulqini), tentang adanya ayat Alquran yang paling utama (afdal), utama (fádil), dan kurang utama (mafdul), meski masalah keutamaan tersebut dipahami berbeda oleh para ulama. ${ }^{12}$ Di samping

10 Abdullah Ahmed An-Naim, Toward an Islamic Reformation: Civil Liberties, Human Rights, and International Law (Syracuse, New York: Syracuse University Press, 1996), xiv.

11 Karya ini dimaksudkan oleh al-Suyūți sebagai pengembangan kajian-kajian 'ulum al-Qur'an. Dengan berpatokan kepada karya al-Bulqini, Mawāqi' al-Ulum, yang mencantumkan 52 tema kajian, al-Suyựti menambah 50 tema dalam Al-Taḅbìr, sehingga menjadi 102 tema. Tambahan dari al-Suyuṭi biasanya dijelaskannya dengan "ini tambahan dari saya" (bädzih ziyadatati).

12 Keutamaan dalam pengertian diamalkan, kandungannya tentang ketuhanan, maupun dalam hal pahala membacanya. Lihat Jalāl al-Din al-Suyūitii, Al-Taḅbì $\bar{i} \mathrm{Tlm}$ al-Tafsìr (Beirut: Dār al-Kutub al-'Ilmiyah, 1988), 140-142. Lihat juga karyanya, Al- 
itu, Ibn al-Muqaffa' (w. 756 M) juga membedakan antara ayat-ayat

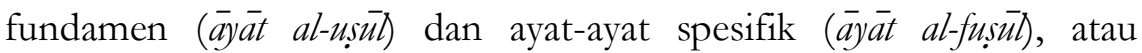
biasanya dikenal juga dengan ayat-ayat ranting ( $\overline{\text { ay }} \overline{\text { at }}$ al-furū $) .13$

Abū Ishạaq al-Shạtibi (w. $790 \quad \mathrm{H}$ ) menyusun karya

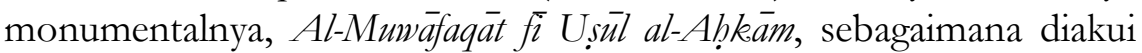
sendiri, antara lain, bertolak dari istiqrä' (induksi, penelitian kasus perkasus) atas ayat-ayat Alquran. ${ }^{14}$ Tidak semua ayat berbicara pada level yang sama, karena terdapat ayat-ayat mengatur prinsip-prinsip yang berlaku umum dan menjadi "payung" (al-kulliyat) berbagai ketentuan spesifik hukum (al-jur, 'iyat), sebagaimana juga hadis-hadis Nabi yang dijadikan, misalnya, sebagai dasar qawäid fiqhiyah. 'Ayat alkulliyat, sebagaimana disinggung, menurut al-Shātibi, adalah ayat-ayat yang memuat ajaran yang bersifat prinsipil dan permanen (tidak bisa dianulir) ${ }^{15}$ tentang perlindungan terhadap agama, jiwa, akal, kehormatan, dan harta. Ayat-ayat tersebut turun sebagian besar di Makkah dan sebagian kecil turun di Madinah sebagai penyempurnaan, yang meliputi ayat-ayat tentang tawhịd, prinsip-prinsip moral (akbläq), dan beberapa ajaran fundamental lain, seperti salat. ${ }^{16}$ Sebaliknya, ‘yat al-juz'iy at adalah ayat-ayat yang berisi ketentuan-ketentuan spesifik atau partikular, tentang suatu masalah, persoalan ranting, atau persoalan rincian (jur', far', atau fasl) seperti ketentuan tentang perang yang sangat kondisional, karena tentu dalam keadaan normal atau damai, perang tidak dianjurkan. Ayat-ayat spesifik atau partikular tentu harus dipahami dalam kerangka rujukan ajat al-kulliyat. ${ }^{17}$ Ketentuan spesifik umumnya tidak bertentangan dengan ketentuan umum, seperti ketentuan perang tidak bertentangan dengan prinsip

Itqān fì 'Ulum al-Qur'ān, vol. 2 (Beirut: Dār al-Fikr, t.th.), 156-160. Bandingkan

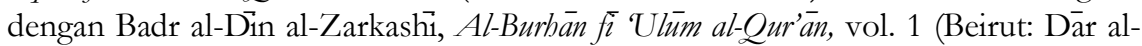
Fikr, 2001), 519-523.

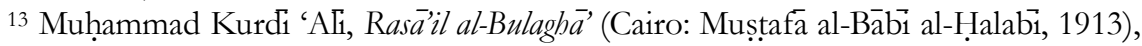
57.

14 Baca Moh Fahimul Fuad, “Asy-Syatibi dan Konsep Istiqra' Ma'nawi," dalam $A$ sSalam: Jurnal Studi Hukum Islam \& Pendidikan, vol. 1, no. 1 (2012), 1-22.

15 Abū Ishāà al-Shạtibī, Al-Muwāafaqāt, ed. 'Abdullāh Dirāaz, vol. 3 (Beirut: Dār alKutub al-'Ilmiyah, t.th.), 338.

16 Al-Shātibi, Al-Muwāfaqūt, vol. 3, 335-336.

17 Moh. Fahimul Fuad, "Maqașid al-Syari'ah dalam Ayat-Ayat Makkiyyah (Study Pemikiran Asy-Syatibi)," dalam IN RIGHT: Jurnal Agama dan Hak Azazi Manusia, vol. 3, no. 1 (2017), 87-110. 
moral yang kemudian membatasi perang hanya dibolehkan jika (telah atau akan) diperangi sebagai perang defensif, larangan agresi, dan larangan membunuh secara berlebihan (membunuh anak-anak, wanita, dan orang tua renta).

Tokoh penting yang lain adalah Mạ̣mūd Muhammad Ṭăhā (w. 1985). Ia membedakan antara "ayat-ayat pokok atau primer" ('ajât alusūi, primary verses) dan "ayat-ayat ranting atau subsider" ('ayat al-furu', subsidiary verses). Yang dimaksud dengan yang pertama adalah ayat-ayat yang memuat prinsip etis yang, karenanya, bersifat abadi dan menjadi inti peradaban kemanusiaan yang telah dibangun oleh Nabi Muhammad. Menurutnya, prinsip etis yang menjadi inti pada syariat meliputi tiga hal, yaitu: (1) keadilan ('adl) (QS. al-Naḥl [16]:90) dalam pengertian hukuman setimpal (QS. al-Mà-idah [5]:45, QS. al-Baqarah [2]:194), (2) memaafkan (atau bahkan berbuat baik) terhadap orang yang berbuat salah (ị̂sān) (QS. al-Mă'idah [5]:45), (3) dan silaturahmi dalam pengertian luas (QS. al-Nahl [16]:90). ${ }^{18}$ Sedangkan, yang dimaksud dengan ayat jenis kedua adalah ayat yang memuat aturanaturan yang bersifat elastis, karena bersifat partikular dan kondisional. Dari segi tipenya, menurutnya, ayat jenis pertama adalah ayat-ayat yang umumnya makkijah, di mana titik-awal dan orisinalitas (așälah) ajaran Islam diletakkan, sedangkan ayat jenis kedua umumnya merupakan ayat-ayat madaniyah yang, karena lebih kondisional, partikular, dan mengalami perubahan, dimaksudkan untuk menampung perubahan (hawalab) yang tunduk pada "hukum waktu" (săhibat al-waqt). Berbeda dengan ayat jenis kedua, ayat jenis pertama tidak bisa dianulir (mansükh), melainkan hanya ditunda penerapannya sesuai dengan konteksnya. ${ }^{19}$

"Misi kedua" (al-risālah al-thäniyah) yang ia maksud adalah misi Alquran yang lebih egaliter, karena memuat persamaan, yang

\footnotetext{
18 Mahmūd Muhammad Țăhāa, Al-Risālah al-Thāniyah min al-Islām, dalam www.alfikra.org/htm. Penulis merujuk ke sumber primer ini. Namun, untuk kepentingan perujukan, penulis menunjuk The Second Message of Islam, terj. Abdullahi Ahmed an-Naim (Syracuse, New York: Syracuse University Press, 1987), 77.

19 Maḥmūd MuhammadṬTTāhā, Al-Qur'an wa Mustafā Mahmūd wa al-Fahm al-'Asrī, dalam www.alfikra.org. Karya ini pertama kali terbit pada 1971. Lihat juga M. Zayin Chudlori, "Gagasan Mahmud Muhammad Taha tentang Evolusi Syariah," dalam Al-Qanun: Jurnal Pemikiran dan Pembaharuan Hukum Islam, vol. 11, no. 1 (2008), 1-26; Roji Fathullah, "Pemikiran Pembaharuan Hukum Islam Mahmud Muhammad Thaha," dalam Tarkiya, vol. 18, no. 1 (2017), 26-49.
} 
umumnya terkandung dalam ayat-ayat makkiyah. Sedangkan, "misi pertama" (al-risālah al-'üla) adalah misi yang termuat dalam ayat-ayat madaniyah yang, karena masyarakat Muslim telah terbentuk, menghendaki perubahan strategi, seperti tercermin dari kewajiban jihad. Karena mempertimbangkan spirit etis ayat-ayat makikiyah, pemberlakuan ayat-ayat madaniyah "ditunda".20 Alasan mendasar "penundaan" tersebut dimungkinkan adalah karena syariat hanya sempurna jika ia berkembang secara evolutif dengan spirit zaman (tatawwur al-shari'ab).

Al-Shātibi dan Tạhā memiliki kesamaan sekaligus perbedaan pandangan. Keduanya mengakui adanya ayat-ayat yang bersifat universal. Bagi Țăhā, ayat-ayat tersebut adalah ayat-ayat yang memuat prinsip etis yang terutama turun pada fase Makkah. Bagi al-Shātibā, ayat-ayat tersebut adalah ayat-ayat yang terkait dengan "patokanpatokan universal" (al-qawā'id al-kulliyah) yang terkait dengan tujuantujuan hukum Islam (maqasid al-shari'ah), baik yang elementer (daruriyat), suplementer (bajiz $\overline{a t})$, maupun komplementer (tabsiniy $\overline{a t}$ ). Kandungan ayat-ayat ini bersifat abadi dan menjadi dasar setiap agama. ${ }^{21}$

Tujuan luhur syariat, meskipun sebenarnya "ijtiba $\bar{d} \bar{\imath}$ " karena disimpulkan secara istigră $\bar{i}$ dari kasus per-kasus, menurut al-Shạtibi tidak akan dianulir sampai kapan pun, karena menjadi dasar bagi Islam, bahkan semua agama, sama halnya prinsip etis, menurut Tăhā, menjadi dasar berbagai ajaran Alquran, sehingga tidak teranulir. Akan tetapi, al-Shătịīi melihat bahwa patokan-patokan universal dimaksud tidak hanya mencakup prinsip etis yang memang diprioritaskan untuk diletakkan fondasinya pada fase dakwah Nabi Muhammad di Makkah,

20 Țăhā, The Second Message, 145. Lihat juga, Moh Abdul Kholiq Hasan, "Ayat-ayat Kebebasan Beragama dalam Perspektif Nasakh: Kajian Terhadap Penafsiran Ibn Kathir dan Rashid Rida," dalam Mutawatir Jurnal Keilmuan Tafsir Hadith, vol. 6, no. 2 (2016).

21 Al-Shạtibī, Al-Muwāfaqūt, vol. 2, 88. Di samping al-Shātibi, sebagian pakar usūul alfiqh lain, seperti al-'Āmidi dan Ibn al-Häjib menambah dengan mukammilät ke dalam masing-masing dari tiga hal tersebut dengan catatan bahwa tambahan ini merupakan kondisi yang memperkuat terwujudnya motif-motif utama shari'ah dan lebih mengkondisikan tercapainya maslahah dan menghindari kemudaratan. Lihat

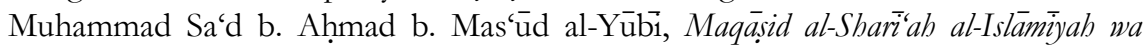
'Alāqatuhā bi al-Adillah al-Sharīyah (Makkah: Dār al-Hijrah li al-Naṣr wa al-Tawzi', 1418/1998), 338-49. 
melainkan prinsip "teologis-etis-ritual" tertentu: (1) prinsip teologis (iman kepada Allah dan hari kiamat), (2) prinsip-prinsip umum ajaran Islam (al-usūl al-ämmah), yaitu perintah-perintah yang meski terkait dengan ibadah tertentu, tapi dianggap sebagai fundamen Islam, seperti salat dan menafkahkan harta, (3) larangan yang terkait dengan isu teologis, seperti larangan menyembelih binatang atas nama selain Allah, dan (4) prinsip-prinsip etis, seperti penekanan Thāhā, seperti keadilan, kejujuran, memberi maaf, dan menolak berdebat dengan cara yang terbaik. Pada umumnya, prinsip-prinsip ini ditanamkan pada fase Makkah. Pada fase Madinah, prinsip-prinsip ini disempurnakan dengan menambah prinsip lain, seperti tentang keringanan (rukbsah). ${ }^{22}$

Ibn 'Āshūr (w. 1973/1393), seorang penafsir modern Alquran asal Tunisia, misalnya, menyatakan di mukadimah karya tafsirnya, $\mathrm{Al}$ Taḩirir wa al-Tanwir, bahwa tugas seorang penafsir Alquran tidak hanya menjelaskan kandungan hukum dalam Alquran secara satu persatu, melainkan ia juga harus menarik hukum-hukum atau patokan yang bersifat universal. ${ }^{23}$ Ibn 'Āshür juga menulis Maqașid al-Shari'ah alIslamiyah, di mana di dalamnya ia mengelaborasi tujuan-tujuan luhur syariat (memelihara agama, jiwa, akal, keturunan, harta, dan kehormatan). ${ }^{24}$ Salah satu metode memahami tujuan luhur itu adalah melalui dalil-dalil Alquran yang ungkapannya jelas dan memuat prinsip yang bisa mengatur ketentuan lain, seperti bahwa Allah tidak menghendaki kerusakan (QS. al-Baqarah [2]: 205), Ia menghendaki kemudahan (QS. al-Baqarah [2]:185), larangan memakan harta orang lain dengan cara yang batil (QS. al-Nisā' [4]: 29), dan seseorang tidak menanggung dosa orang lain (QS. al-An'am [6]:164). ${ }^{25}$ Memang, para ulama telah mengingatkan bahwa hukum Islam ada yang bisa dijelaskan alasan ('illah) di balik penetapan hukumnya, ada yang tidak bisa sama sekali ( a'a $\left.^{\prime} a b u d \bar{l}\right)$, dan ada yang masih samar 'illah-nya. ${ }^{26}$ Ayat

\footnotetext{
22 Al-Shātibi, Al-Muwäafaqāt, vol. 2, 77-78.

23 Muhammad al-Ṭāhir b. 'Āshūr, Al-Taḥrìr wa al-Tanwìr, vol. 1 (Tunis: Dār Suhnūn li al-Naṣr wa al-Tawzi', 1997), 13.

${ }^{24}$ Muhammad Aziz, "Reconstruction of Maqashid Shari'ah Perspective Muhammad Thahir Ibn 'Assyria: Efforts to Re-Discuss Sharia with Reality," dalam Jurnal Hukum Islam, vol. 12, no. 2 (2019), 231-249. Lihat juga, Kusmana, "Epistemologi Tafsir Maqasidi," dalam Mutawatir Jurnal Keilmuan Tafsir Hadith, vol. 6, no. 2 (2016).

${ }^{25}$ Muhammad al-Ṭăhir b. "Āshūr, Maqăsid al-Shari'ah al-Islamìyah (Tunis: Dār Suhnūn li al-Naṣr wa al-Tawzì' dan Kairo: Dār al-Salām, 2008), 18.

${ }^{26}$ Ibid., 42.
} 
Alquran yang berkaitan dengan yang ta'abbudī tidak bisa dinalar, seperti berkaitan dengan bagian waris, tidak bisa dinalar atas dasar kedekatan dan "kebermanfaatan" kerabat tertentu (QS. al-Nisā" [4]:11). ${ }^{27}$ Namun, begitu banyak ayat-ayat lain yang memuat prinsipprinsip ajaran Islam yang universal yang bisa dinalar dan dianalogikan dengan kasus-kasus spesifik di bawah naungannya, bahkan menjadi prinsip Islam abadi.

'Abd al-Raḥmān b. Nāṣir al-Sa'di (w. 1376 H) menulis 71 kaidah untuk menafsirkan Alquran dalam karyanya, Al-Qawāi $i d$ al-Hisān fī Tafsir al-Qur'an. Menariknya, ternyata dari 71 kaidah tersebut, menurut Khālid b. 'Uthmān al-Sabt, hanya sekitar 20 yang bisa dianggap sebagai kaidah tafsir (qawä id al-tafsiri), sedangkan selainnya adalah qawa'id Qur'aniyah, seperti kebiasaan Alquran membicarakan janji kenikmatan (wa'd) sering diiringi dengan janji siksaan (wa"id), dan makna yang masih tersembunyi (latäifi, fawäidd. ${ }^{28}$ Memang, tidak semua kaidah tafsir disepakati keberlakuannya dalam menjelaskan ayat-ayat Alquran, karena sebagian di antaranya masih kontroversial. ${ }^{29}$ Namun, di sela-sela mengemukakan kaidah tafsir, al-Sa' $\overline{d i}$ juga mengemukakan kaidah universal yang sebenarnya tidak berlaku dalam tafsir, melainkan dalam kehidupan, pemikiran, dan tindakan, pada tataran teologis, fikih, dan moral. Kaidah ke-24, misalnya, berbunyi: "Moderasi, Keseimbangan, dan Celaan terhadap Sikap Berlebihan" dengan merujuk QS. al-Nahl [16]: 9030 dan QS. al-A'rāf [7]: 29.31 AlSa'di memberikan contoh-contoh penerapan moderasi (al-tawassut) dan keseimbangan (al-itidāl) dalam beberapa hal terkait ibadah (sesuai petunjuk Nabi), mencintai para Nabi, ulama, dan awliyà (tidak mengkultuskan), membelanjakan harta (tidak boros dan kikir), keberanian (tidak pengecut dan nekat), dan berbuat baik kepada kedua

\footnotetext{
${ }^{27}$ Ibid., 43.

${ }^{28}$ Khālid b. 'Uthmān al-Sabt, Qawāi id al-Tafsìr: Jam'an wa Dirāsatan (Giza, Mesir: Dār Ibn 'Affan, $1421 \mathrm{H}), 44$.

${ }^{29}$ Ibid., 46-47.

30 Ayat tersebut berbunyi: Sesungguhnya Allah menyuruh (kamu) berlaku adil dan berbuat kebajikan.

31 Ayat tersebut berbunyi: Katakanlah, "Tuhanku menyuruh menjalankan keadilan."
} 
orang tua dan kerabat (tidak kurang dan lebih).32 Keadilan adalah prinsip yang mengatur keseluruhan pelbagai aturan dalam Islam. ${ }^{33}$

Banyaknya cakupan terapan kedua prinsip ini menunjukkan bahwa kedua prinsip sangat universal. Meski al-Sa di memberikan contoh-contoh terapan seperti itu, sebenarnya kedua prinsip yang saling terkait ini menjadi hukum kosmis yang sudah ditetapkan oleh Tuhan sejak awal penciptaan. Di lain ayat, ide Alquran tentang keseimbangan diungkapkan dengan "miza à" (neraca) dalam firmanNya, "Dan Allah telah meninggikan (rafa'a) langit dan Dia meletakkan (wada'a) neraca, supaya kamu tidak melampuai batas dalam neraca itu, dan tegakkanlah timbangan itu dengan adil (qist) dan jangan kamu mengurangi neraca itu. Allah telah menciptakan bumi untuk makhluk(-Nya)" (QS. al-Raḥmān [55]: 7-10). Alur pembicaraan ayat ini bergerak dari penciptaan fisik ke pengaturan sosial-ekonomi (timbangan). Ayat ini, yang sealur dengan ayat keseimbangan yang dikutip al-Sa' $\overline{d i}$, adalah ayat yang memuat keseimbangan kosmis yang tidak hanya berlaku di dunia fisika, melainkan juga di ranah sosial. ${ }^{34}$

Ibn Kathir menafsirkan ayat 9 surah tersebut dengan mengatakan, "Dia (Tuhan) menciptakan langit dan bumi dengan kebenaran (bertujuan) dan keadilan, agar segala sesuatu berjalan dengan kebenaran dan keadilan" (khalaqa al-samāwat wa al-ard bi al-haqq wa al-'adl li takūn al-ashyà' kullubà bi al-ḥaqq wa al-'adb.35 Jadi, keadilan sosial adalah bagian dari tuntutan keseimbangan kosmis. Ide yang ditarik dari ayat ini dan ayat yang dikutip al-Sa'di bersifat universal, bahkan melampaui batas cakupan terhadap mat Islam, karena penodaan terhadap keadilan, sebagai pelanggaran hukum jagat raya, akan berakibat kehancuran, siapa pun pelakunya dan penganut agama apa pun.

Para ulama di atas, baik al-Suyūṭi, Ibn al-Muqaffa', al-Shāṭibi, Ṭăhā, Ibn 'Āshūr, maupun al-Sa'di, meski dengan formulasi dan sudut

\footnotetext{
32 Al-Sa'đi, Al-Qawä ìd al-Hisān, 56-57.

33 Lihat Ibn Qayyim al-Jawziyah, I'lam al-Muwaqqi $\bar{i}$, vol. 3 (Kairo: Dār al-Hadith, 2004), 5.

${ }^{34}$ Lihat Wardani, Islam Ramah Lingkungan: dari Eko-teologi al-Qur'an hingga Fiqh alBi ah (Banjarmasin: IAIN Antasari Press, 2015), 61-65; Nurcholish Madjid, "Kalam Kekhalifahan dan Reformasi Bumi (Suatu Percobaan Pendekatan Sistematis terhadap Konsep Antropologis Islam)", pidato pengukuhan guru besar luar biasa dalam falsafah dan kalam, IAIN Syarif Hidayatullah, Jakarta, 1419/1998, 27-30.

35 Ibn Kathir, Tafsì al-Qur'an al-'Ażim, vol. 4, 271.
} 
pandang berbeda, sama-sama berpendapat bahwa ayat-ayat Alquran, meski turun dari Tuhan yang sama, levelnya berbeda dalam hal partikularitas-universalitas. Di samping, menjelaskan hukum (teologis, fikih, dan etis) sesuatu secara spesifik, kasus per-kasus, Alquran juga menuangkan segala sesuatu terkadang dalam ungkapan yang maknanya bisa dipahami memiliki cakupan universal. Alquran memuat dua sisi tersebut: partikuralitas (lokalitas-temporalitas) dan universalitas, insidental dan intrinsik, mikro dan makro, historis dan

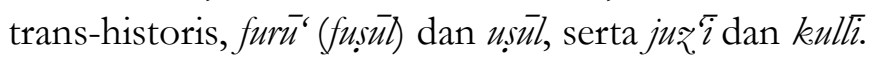

\section{Mencari Universalitas (Kulliyah) Nilai Alquran: Analisis Gerak Makna Ayat}

Alquran sebagai teks baku yang sudah diterima (textus receptus) sebagaimana termaktub dalam mushaf yang kita baca adalah tetap teksnya (6.236 ayat menurut salah satu penghitungan). Akan tetapi, meski bentuk (shakl, form) nass. bersifat tetap, isi (madmun, content) atau pemaknaannya dipahami berbeda oleh penafsir berbeda, karena perspektif dan metode yang digunakan atau bisa juga karena ayat yang multi-tafsir. Ketika itu, nas ayat tetap, tapi maknanya bergerak, demikian istilah Muhammad Shahrūur ${ }^{36}$ dan Aḥmad al-Baḥrāni (Shii $\left.\bar{i}\right) \cdot{ }^{37}$ Persoalan partikularitas-universalitas adalah persoalan tentang "gerak makna". Bagaimana menarik pesan-pesan universal Alquran, meski ayat-ayat yang turun tercerai-berai dalam kurun waktu sejarah panjang dan dalam konteks berbeda juga? Mungkinkah dari partikularitas ayatayat Alquran yang turun bisa ditarik pesan-pesannya yang bersifat universal?

Dengan bertolak dari pemikiran Muhammad 'Abduh tentang tafsir terbaik Alquran adalah Alquran sendiri, Muhammad Asad dalam The Message of the Qur'an menyatakan bahwa universalitas pesan Alquran bisa diperoleh dengan meletakkan asumsi bahwa sebagai kitab suci, Alquran bukanlah semata kumpulan berbagai perintah dan larangan, melainkan ada kesatuan ide yang secara inheren

\footnotetext{
${ }^{36}$ Lihat Andreas Christmann, "The Form is Permanent, But the Content Moves: the Qur'anic Text ad Its Interpretation(s) in Mohamad Shahrour's al-Kitāb wa alQur'an," dalam Modern Muslim Intellectual and the Qur'an, ed. Suha Taji-Farouki (London: The Institute of Ismaili Studies, 2004).

${ }^{37}$ Lihat Aḥmad al-Bahrāni, Al-Ta'wīl Manhaj al-Istinbät fí al-Islam: Dirāsab fí al-Tärikeh wa al-Turäth wa al-Fiker Takshif 'an Ma'älim Manhaj al-Istinbät 'ind al-Rasūl wa Abl alBayt wa al-Sahāabah (t.tp.: Dār al-Ta'wil, 1999).
} 
menghubungkan antar ayat, antar surah, bahkan keseluruhan Alquran. Makna integral bisa diperoleh dengan melakukan rujuk-silang (crossreference) dengan menggeser yang insidental ke intrinsik, atau yang partikular ke general (universal). Asad menyatakan sebagai berikut:

"The Qur'an must not be viewed as a compilation of individual injunctions and exhortations, but as one integral whole, that is, as an exposition of an ethical doctrine in which every verse and sentence has an intimate bearing on other verses and sentences, all of them clarifying and amplifying one another. Consequently, its real meaning can be grasped only if we correlate every one of its ideas by means of frequent cross-references, always subordinating the particular to the general and the incidental to the intrinsic. Whenever this rule is faithfully followed, we realize that the Qur'an is - in the words of Muhammad 'Abduh_ " "its own best commentary."'"38

"Alquran seharusnya tidak dilihat hanya sebagai sebuah kompilasi perintah-perintah dan larangan-larangan yang terpisah, melainkan sebagai suatu kesatuan yang integral, yaitu sebagai suatu penjelasan rinci tentang ajaran etika yang di dalamnya setiap ayat dan kalimat memiliki hubungan erat, semuanya saling menjelaskan dan memperkuat. Sebagai konsekuensinya, makna sesungguhnya hanya bisa dipahami, jika kita menghubungkan setiap idenya satu persatu dengan cara rujuk silang (cross-reference), yang selalu dilakukan dengan menggeser yang partikular ke yang general dan yang insidental ke yang intrinsik. Kapanpun jika aturan ini diikuti secara tepat, kita sadar bahwa Alquran-dalam ungkapan Muhammad 'Abduh—adalah "tafsirnya yang terbaik."'

Di samping pemikiran Asad dan 'Abduh, pemikiran Ṭăhā patut dipertimbangkan. Meski tampak ada reduksi terlalu kuat terhadap ajaran Islam ke nilai-nilai etis, Țăhā benar dengan mengatakan bawa ayat al-furu' (meski tidak bisa diidentikkan seluruhnya dengan ayat-ayat madaniyah) harus dipahami dalam kerangka rujukan ay ât al-usūl (meski tidak bisa diidentikkan seluruhnya dengan ayat-ayat makkijyab). Ay $\overline{a t}$ alfurü' karena konteks spesifik dan kondisionalnya, seperti $\overline{a y} \overline{a t}$ al-jib $\overline{a d}$ (ayat-ayat tentang jihad) yang didesak oleh kepentingan membela diri dan tidak berlaku di setiap keadaan, harus dikembalikan, "dianulir

38 Muhammad Asad, The Message of the Qur'an (Gibraltar: Dār al-Andalus, 1980), vii. Lihat juga: Nadzrah Ahmad and Ahmad Nabil B. Amir, "Muhammad Asad's the Message of the Qur'an," dalam Sociology and Anthropology, vol. 1, no. 12 (2016), $1117-$ 1120 . 
secara temporal", atau "ditunda", dengan merujuk àyat al-usül yang permanen.

Ide Țăhā ini memiliki persamaan dengan "gerak ganda" (double movement) Fazlur Rahman. Alquran, menurut Rahman, memuat ajaran

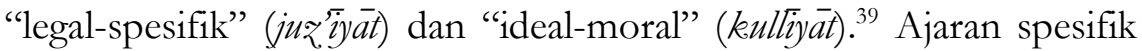
harus dipahami secara integral dengan yang kedua secara dinamis dan sirkular. Hanya saja, Rahman mengingatkan bahwa forma (aturan spesifik, juz'? $\bar{\imath}$ sama pentingnya dengan esensi (prinsip ideal-moral). Yang harus dihindari bukan forma, melainkan formalisme, tegasnya. ${ }^{40}$ Pernyataan ini bertujuan untuk mengurangi resiko "reduksi etis", seperti pada Ṭāhā, meski Rahman sendiri bisa jatuh menjadi "esensialis" yang hanya mementingkan ideal-moral. ${ }^{41}$

\section{Skema: Gerak Ganda (double movement) Fazlur Rahman ${ }^{42}$}

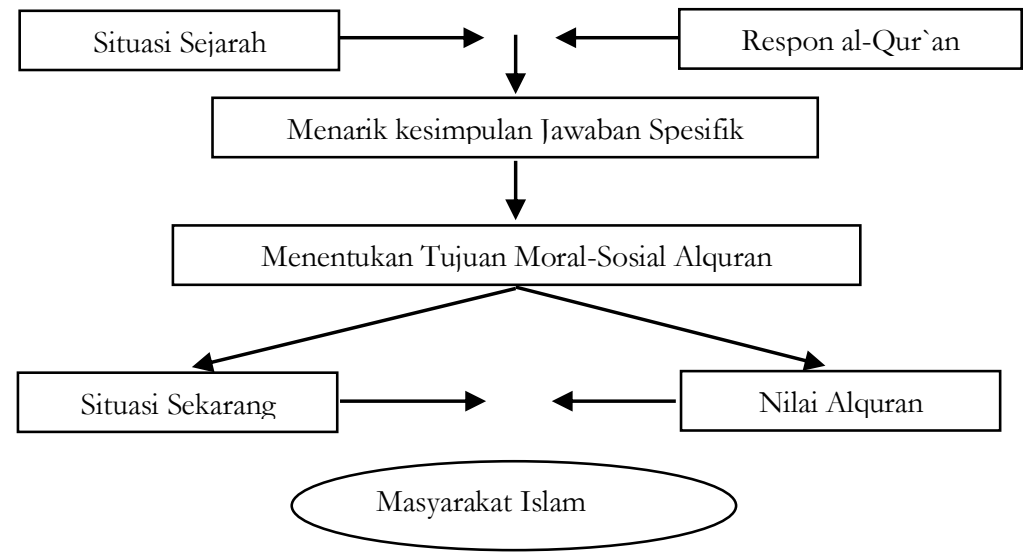

Metode Fazlur Rahman ini di satu sisi memang masih mendapat kritik. Farid Esack, misalnya, mengritiknya karena "kurang memperhatikan kompleksitas tugas hermeneutik dan keragaman intelektual yang menyatu di dalamnya". ${ }^{43}$ Maksud Esack adalah

${ }^{39}$ Fazlur Rahman, "Islam: Challenges and Opportunities", dalam Islam: Past Influence and Present Challenge, ed. Alford T. Welch dan Pierre Cachia (Edinburgh: Edinburgh University Press, 1979), 325-326.

40 Fazlur Rahman, "Social Change and Early Sunnah", dalam Hadith and Sunnah: Ideals and Realities, ed. P.K. Koya (Kuala Lumpur: Islamic Book Trust, 1996), 231.

${ }^{41}$ Lihat penafsiran tentang tentang keselamatan agama-agama, Fazlur Rahman, The Major Themes of the Qur'an (Minneapolis: Bibliotheca Islamica, 1989), 166.

42 Farid Esack, Qur'an, Liberalism, and Pluralism: An Islamic Perspective of Interreligious Solidarity Against Oppression (Oxford: Oneworld, 1997), 66.

43 Ibid., 67. 
konsep tentang iman, misalnya, tidak bisa dilihat berdiri sendiri, terlepas dari bagaimana faktor politik bisa mempengaruhi pemahaman tentangnya yang akan berpengaruh terhadap tindakan. Ebrahim Moosa, seperti dikutip Esack, juga mengritiknya, karena dia tidak berupaya menangkap keseluruhan estetik, tapi ia didesak oleh tugasnya untuk mengungkap nilai moral. ${ }^{44}$ Dalam beberapa kasus penafsiran yang diajukan oleh Rahman, menurut penulis, "reduksi etis" yang tampak terlalu kuat bisa dirasakan, seperti persoalan keselematan (salvation) agama-agama di luar Islam di akhirat nanti. ${ }^{45}$

Di sisi lain, metode Rahman menunjukkan pentingnya memahami berbagai ketentuan Islam dalam Alquran atas dasar elan vitalnya, yaitu ideal-moral. Persoalan yang dihadapi sekarang adalah bahwa para penafsir sering "terkotak" pada partikularitas ayat, seperti perintah berperang yang sebenarnya elastis dan kondisional atas dasar pertimbangan moral (defensif) kemudian secara keliru dianggap

\footnotetext{
44 Ibid.

45 Berkaitan dengan QS. al-Baqarah [2]: 62 dan QS. al-Mà-idah [5]: 69, dia menyatakan, "In both these verses, the vast majority of Muslim commentators exercise themselves fruitlessly to avoid having to admit the obvious meaning: that those-from any section of humankind - who believe in God and the Last Day and do good deeds are saving. They either say that by Jews, Christians, and Sabaeans here meant those who have actually become "Muslims"which interpretation is clearly belied by the fact that "Muslims" constitute only the first of the four groups of "those who believe" - or that they were those good Jews, Christians, and Sabaeans who lived before the advent of the Prophet Muhammad — which is an even worse tour de force.
}

Pada kedua ayat tersebut [QS. al-Baqarah [2]: 62 dan al-Mā'idah [5]: 69], mayoritas besar penafsir muslim berupaya dengan tanpa membuahkan hasil untuk menghindari menerima pengertian yang jelas bahwa orang yang percaya dengan Tuhan dan hari akhir serta melakukan perbuatan baik, dari mana pun, adalah selamat. Mereka adakalanya mengatakan bahwa yang dimaksud dengan Yahudi, Kristen, dan Sabi'in di sini adalah yang sesungguhnya telah menjadi "muslim", suatu penafsiran yang jelas bertentangan dengan kenyataan bahwa "muslim" di sini hanya merupakan kelompok pertama dari empat kelompok tersebut, atau adakalanya yang dimaksud adalah Yahudi, Kristen, dan Sabi'in yang hidup sebelum kedatangan Nabi Muhammad, yang bahkan merupakan penafsiran yang lebih keliru. Rahman, Major Themes, 166. Bandingkan dengan Asad, The Message of the Qur'an, 14.

Syarat "keimanan" dalam kedua ayat di atas ditarik ke ideal moral yang disimpulkan dari QS. al-Màidah [5]: 48, QS. al-Baqarah [2]: 148, dan 177 yang menjelaskan bahwa perbedaan agama-agama dan kitab suci yang diturunkan pada prinsipnya adalah sama, karena esensi tujuan agama juga sama, yaitu fastabiqū al-khayrät (berlomba-lombalah dalam kebajikan). Keyakinan teologis yang berbeda-beda adalah forma (bentuk), sedangkan kebaikan (etika) adalah esensi atau tujuan idealmoral Alquran. Di sini, prinsip teologis tersebut direduksi menjadi prinsip etis (ideal-moral). 
sebagai perintah abadi hingga kiamat, dengan tidak melihat bahwa benang-merah yang menghubungkan berbagai perintah dan larangan adalah prinsip etis. ${ }^{46}$ Tidak mungkin ada ayat yang bisa ditafsirkan tercerabut dari ajaran moral Alquran.

"Gerak ganda" dalam memahami universalitas nilai-nilai Alquran terdiri dari dua gerakan. Gerakan pertama, dari situasi sekarang ke masa ketika Alquran diturunkan. Ini dilakukan dengan dua langkah: (1) memahami arti dari suatu pernyataan dengan mengkaji situasi atau problem historis, di mana pernyataan Alquran tersebut adalah jawaban terhadapnya; (2) menggeneralisasi jawaban-jawaban spesifik dan merumuskan tujuan moral-sosial umum dengan menyaring dari ayat-ayat spesifik melalui pemahaman terhadap latar belakang sosiohistoris dan ratio legis (alasan hukum) yang sering disebutkan. Gerakan pertama ini bergerak dari jawaban spesifik ke prinsip umum. ${ }^{47}$

Gerakan kedua, dari masa ketika Alquran diturunkan ke masa sekarang. Gerakan kedua ini bergerak dari prinsip umum (berupa nilai moral Alquran) ke situasi sekarang, dalam pengertian bahwa ajaranajaran yang bersifat umum tersebut harus diwujudkan dalam konteks sosio-historis sekarang. ${ }^{48}$

Contoh yang dikemukakan oleh Fazlur Rahman adalah poligami. Ijin berpoligami muncul dalam konteks penekanan pentingnya keadilan berkaitan dengan perlakuan para wali terhadap anak yatim (QS. al-Nisā' [4]: 3). Dalam QS. al-An'àm [6]: 2, Alquran mengutuk para wali anak yatim, karena menyelewengkan harta kekayaan mereka. Persoalan ini ditekankan di Makkah (QS. al-An‘am [6]:152; QS. alIsrā', [17]:34) dan di Madinah (QS. al-Baqarah [2]:220; QS. al-Nisā' [4]:2,6,10,127). Dalam konteks serangkaian ayat-ayat yang turun untuk menekankan keadilan ini (lihat juga QS. al-Baqarah [2]:83, 177, 215; QS. al-nisā' [4]:8, 36; QS. al-Fajr [89]:17; QS. al-Ḍuhā [93]:9; QS. al$M^{-} a^{-} u ̄ n$ [107]:2), Alquran membolehkan para wali tersebut menikahi sampai empat di antara anak-anak perempuan yatim asuhannya, asalkan mereka bisa berlaku adil.

\footnotetext{
46 Baca Ulya Ulya, "Hermeneutika Double Movement Fazlur Rahman: Menuju Penetapan Hukum Bervisi Etis," dalam ULUL ALBAB Jurnal Studi Islam 12, no. 2 (September 18, 2013): 111-127.

47 Fazlur Rahman, Islam dan Modernitas, terj. Ahsin Mohammad (Bandung: Pustaka, 1995), 7.

48 Ibid., 7-8.
} 
Menurut Fazlur Rahman, ada semacam "kontradiksi" antara ijin berpoligami tersebut dengan tuntutan berlaku adil yang tidak mungkin terwujud sesungguhnya (QS. al-Nisā' [4]:129). Menurut penafsiran tradisional, poligami berstatus hukum diijinkan, meski keadilan diserahkan sepenuhnya kepada suami. Sedangkan, menurut penafsiran modernis Muslim, ijin poligami bersifat temporal, dan keadilan tidak mungkin terwujud. Fazlur Rahman memilih pendapat bahwa poligami sesuai dengan skenario hukum, sedangkan sanksinya adalah untuk mencapai ideal moral yang harus diperjuangkan oleh masyarakat, karena poligami tidak mungkin dihilangkan. Kasus hukumnya sama dengan perbudakan. Dengan memahami situasi sosio-historis dan ratio legis-nya, poligami adalah legal, namun keadilan adalah nilai yang harus diperjuangkan. ${ }^{49}$

Agaknya, karena nilai keadilan tidak mungkin terwujud sempurna, bagi Fazlur Rahman, sebenarnya monogami adalah tawaran ideal yang ingin diwujudkan, seperti halnya perbudakan. Itu artinya, bagi Rahman, Alquran berproses menuju ideal, sama dengan pandangan Sa $\bar{i}$ d al-'Ashmāwi bahwa "Metode Alquran adalah bergerak secara evolusioner menuju yang ideal" (manhaj al-Qur'an al-tatawwur ilà alafdab..$^{50}$ Dengan demikian, dimensi moral Alquran harus menjadi rujukan berbagai aturan, karena tidak mungkin aturan-aturan spesifik yang terkadang kondisional bertentangan dengan nilai moral yang mendasarinya. Terlepas dari kritik-kritik ini, para pakar Alquran samasama menyarankan untuk memahami ayat secara integral, tidak lepas dari ayat-ayat yang dimensinya universal dan permanen. Alasan lain mengapa ajaran moral perlu dirujuk adalah karena, sebagaimana dikemukakan Ibn al-Mubārak (w. $181 \mathrm{H}$ ), penulis pertama tentang jihăd, hampir dua pertiga (2/3) dari ajaran Islam berisi ajaran moral. ${ }^{51}$

Prinsip moral yang menjadi rujukan di sini sama pentingnya dengan prinsip teologis, karena keduanya saling terkait. Dalam hadis, dinyatakan, "orang mukmin yang paling sempurna imannya adalah

\footnotetext{
${ }^{49}$ Fazlur Rahman, Major Themes, 48. Lihat Zunly Nadia, "Membaca Ayat Poligami Bersama Fazlur Rahman," dalam Mukaddimah: Jurnal Studi Islam, vol. 2, no. 2 (2018): 203-228; Fahmi Ulyati, "Pemikiran Fazlur Rahman Dalam Q.S. An-Nisā' [4]: 3 Tentang Poligami," dalam SYARIATI, vol. 3, no. 01 (2017): 15-24.

${ }^{50}$ Lihat karyanya Usūl al-Shari'ah (Cairo: Maktabah Madbūli dan Beirut: Dār Iqra', 1983).

51 'Abdullāh b. al-Mubārak, Kitāb al-Jihād, ed. Naz̄ih Hammād Jaddah: Dār alMatbu' 'at al-Hadithah, t.th.), 37.
} 
yang paling baik akhlaknya". ${ }^{52}$ Oleh karena itu, nilai moral dan akidah sulit dipisahkan. Jika Fazlur Rahman menekankan prinsip ideal-moral, Jamāl al-Dīn 'Atìyah, mengemukakan hirarki nilai dalam konteks teori dan kaidah dalam usū al-fiqh yang bisa menjembatani kesenjangan hukum spesifik dan nilainya.

Dalam skema berikut prinsip moral dan teologi berada di puncak pada level yang sama: ${ }^{53}$

\section{Skema: Hirarki Nilai Jamāl al-Dīn 'Atìyah}

Aqidah, Moral, dan Nilai-nilainya

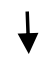

Teori-teori Umum Shari'ah

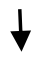

Kaidah dan Teori Terkait Beberapa/Satu Hal

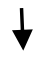

Teori-teori Khusus

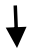

Hukum-hukum Spesifik/Cabang

Terhadap tawaran 'Ațiyah di atas berkaitan dengan keharusan melihat ayat-ayat terutama yang berkaitan dengan perintah dan larangan, penulis bisa memberi catatan sebagai berikut. Dalam memahami ayat, di samping konteks historis, baik makro sebagaimana diusulkan oleh Rahman, ${ }^{54}$ Hādi Ma rifat, ${ }^{55}$ maupun Sa ${ }^{\bar{i}} \mathrm{id}$ al-'Ashmāwi ${ }^{56}$

\footnotetext{
52 Lihat, misalnya, al-Ḥākim, Al-Mustadrak 'alā al-Saḥiḩayn, vol. 1, ed. Muṣtafá 'Abd al-Qādir "Ața" (Beirut: Dār al-Kutub al-'Tlmiyyah, 1990), 43. Sayangnya, secara teologis, terutama dalam perspektif Sunni, diyakini bahwa orang yang tidak bermoral sekalipun, seperti pendosa besar (murtakib al-kabä'iir), namun beriman, tetap selamat (najăb) di akherat, tapi tidak sebaliknya. Hingga batas tertentu, cara pandang ini akan menurunkan moralitas dalam keyakinan, meski kalangan Sunni memiliki konsep fluktuasi (berkurang bertambah) iman.

53 Diadaptasi dan dimodifikasi dari Jamāl al-Dìn 'Ațiyah, Al-Tanżir al-Fiqh (Qatar: t.p., 1987/1407), 12.

${ }^{54}$ Lihat Fazlur Rahman, Islam and Modernity, Transformation of an Intellectual Tradition (Chicago: The University of Chicago, 1982), 143.

55 Muhammad Hāđi Ma'rifah, Sejarah al-Qur'an, terj. Thoha Musawa (Jakarta: alHuda, 2007), 97-101.
} 
dengan pemahaman perangkat sejarah, biografi, dan hadis-hadis sejarah, maupun mikro melalui sabab al-nuгū baik melalui konteks historis internal ayat maupun riwayat-riwayat sahih, kita perlu secara operasional merujukkan ayat ke-"kesatuan/unit nilai" (wibdat alqimah). ${ }^{57} \mathrm{Hal}$ ini sealur dengan apa yang ditawarkan oleh Țāhā, Jābir al-'Alwāni tentang tujuan-tujuan Alquran yang tinggi dan menjadi rujukan (al-maqāsid al-Qur'aniyah al-ulyä al-häkimah), yaitu tujuan-tujuan universal. ${ }^{58}$ Perbedaannya adalah bahwa konsep al-'Alwāni memiliki cakupan luas sebagai tujuan agama Islam yang melampaui semua risalah para rasul. Sedangkan, yang dimaksud di sini adalah tujuantujuan universal Alquran itu sendiri yang menaungi tujuan-tujuan spesifik lain. Pemahaman secara integral sebab atau alasan di balik suatu perintah/larangan bisa mengurangi terisolasinya ayat-ayat spesifik dari kerangka ajaran fundamentalnya, baik yang dijelaskan dalam (1) ayat yang sedang dibahas maupun (2) secara rujuk-silang diketahui dari sekian ayat-ayat lain yang terkait. Dengan wihdat alqimah, dibedakan antara: (1) perintah (amr) dan larangan (naby) yang menjadi sarana (wäsitab) tercapainya suatu tujuan (ghayab); (2) tujuan yang ingin dicapai; (3) nilai (qimah) sebagai tujuan akhir yang mendasari tujuan tadi dan terwujudnya perintah atau larangan.

Dengan tambahan di atas, cara memahami universalitas ayat Alquran yang turun dalam konteks partikular sebagai berikut:

\footnotetext{
56 Muhammad Sa⿳亠̄id al-'Ashmāwì, Usül al-Sharī'ah, 64-70.

${ }^{57}$ Yang dimaksud nilai di sini adalah lima prinsip universal (al-kulliyyät al-khams) yang dikemukakan oleh al-Shātibī, jadi nilai memuat tidak hanya moralitas, melainkan juga pandangan otentik mendasar teologis al-Qur`an, bukan kecenderungan pandangan sekte-sekte teologi.

58 Țăhā Jābir al-'Alwāni, Naḥwa al-Tajdìd wa al-Ijtihād (Cairo: Dār Tanwir, 2008), 194196.
} 
Skema: Metode sintesis untuk menyatukan "gerak makna" partikularuniversal

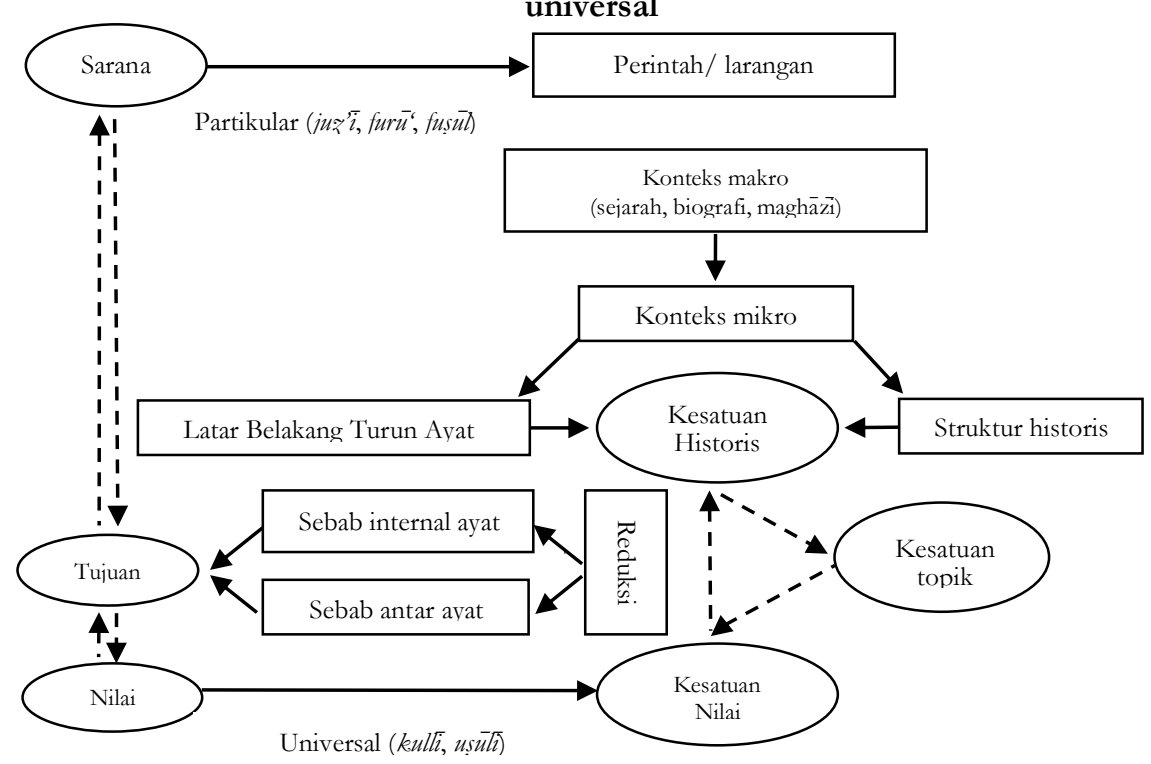

\section{Menelusuri Nilai (Value) di Balik Regulasi Perang dalam Alquran: Sebuah Contoh}

Sebagai contoh, dalam literatur-literatur 'ulum al-Qur'an dan tafsir, bahkan fikih, disebutkan telah terjadinya penganuliran ayat-ayat damai dengan "ayat pedang". Sebenarnya, persoalan ini bisa dipahami ulang dengan mempertimbangkan baik-baik usulan pemikiran tokoh-tokoh di atas untuk memahami ayat-ayat spesifik (regulasi perang yang kondisional) dalam "payung" ayat-ayat universal (memuat alasan moral yang menjadi alasan regulasi perang).

Metode seperti ini diproyeksikan menjawab sebagian problem yang muncul berkaitan dengan ayat-ayat perang yang turun kondisional dan dengan alasan berbeda dalam sejarah Islam. Dalam banyak ayat tersebut, kebolehan berperang dijelaskan alasannya (seperti terzalimi, diperangi, diusir, dihalangi masuk masjid, diejek, dan dibunuh) dan tujuannya (agar penindasan atau "fitnah" tidak terjadi lagi, dan agama Islam berkembang secara alami sebagaimana agamaagama lain) yang disebut sebagai "perang di jalan Allah". Sedangkan, nilai sebagai tujuan akhirnya adalah terpenuhinya hak setiap manusia untuk hidup secara damai tanpa ancaman dan penindasan orang lain, dan hak setiap orang memeluk agamanya, dalam hal ini Islam. Pembedaan antara "sarana" (wasitah, wasìlah) dan "tujuan" (ghāah, 
maqsad) dikemukakan di sini karena memang hukum yang berisi perintah atau larangan yang terkandung dalam Alquran, sejauh tidak menyangkut persoalan ta'abbudi yang tidak bisa dijelaskan alasannya (ta'til al-ạ̧keam), memang berisi dua hal ini.

Badr al-Din al-Zarkashi, misalnya, sebagaimana dikutip oleh Shihāb al-Dīn al-Alūsi dalam Sufrat al-Zäd li Safarat al-jibäd, berpendapat bahwa jihäd (perang) adalah "kewajiban hanya sebagai sarana" (fardìyat al-wasa'il), bukan "kewajiban sebagai tujuan" (fardìyat al-maqasid), karena tujuannya adalah memberi petunjuk (mengawal keamanan dakwah), sehingga jika bisa tercapai dengan mengemukakan penjelasan argumen, tentu cara tersebut diprioritaskan. Namun, mayoritas ulama berpendapat bahwa jih $\bar{a}$ adalah 'kewajiban sebagai tujuan'. ${ }^{59}$ Dalam ungkapan Kāmil Salāmah al-Diqs, "perang bukanlah kaidah, melainkan hanya pengecualian dari kaidah" (inna al-ḥarb (sic: al-ḥurūb ?] laysat hiya al-qā'idah, wa innamā biya istithna $\bar{a}$ min al-qä (idah), karena perang hanya sarana pertahanan diri untuk mengamankan proses dakwah damai Islam. ${ }^{60}$ Persoalan ini menjadi krusial karena menempatkan jihäd (perang) sebagai tujuan akan mengakibatkan hubungan antar agama tidak pernah akan harmonis. Hal itu adalah cerminan dari kegagalan membedakan antara ajaran Alquran yang fundamental dan yang kondisional.

"Rasionalisasi" jibăd bisa dipahami dengan merujuk ke keterangan riwayat-riwayat asbāb al-nuұ̄ul yang berisi latar belakang turun ayat. Di samping itu, riwayat sebagai sumber eskternal, historisitas bisa dipahami dari sumber internal ayat, karena asbäb al-nužl idealnya berinteraksi dengan makna ayat, sebagaimana diusulkan beberapa pakar. Sebagian ayat Alquran memuat alasan ditetapkannya suatu hukum pada suatu ayat, atau dengan rujuk-silang beberapa ayat. Dalam firman Allah (QS. al-Baqarah [2]:193) ini, misalnya, "Perangilah mereka sampai tidak ada lagi penindasan (fitnah) dan agama untuk Allah. Jika mereka berhenti (memusuhimu), tidak ada lagi permusuhan, kecuali terhadap orang-orang yang berbuat zalim" memuat perintah, tujuan, dan nilai. Di samping melalui riwayat, tujuan perang di sini dipahami melalui penggunaan ḅattā (li al-ghājah,

\footnotetext{
59 Shihāb al-Dìn al-Âlūisi, Sufrat al-Zād li Safarat al-Jihăd, 6-7 dalam www.mostafa.com.

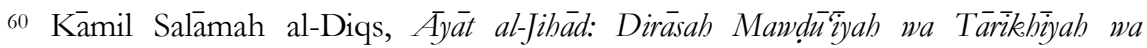
Bayāniyah (Kuwait: Dār al-Bayān, 1392/1972), 261.
} 
menjelaskan tujuan) dan kalimat yang mengiringi. Kata "fitnah" termasuk kosa-kata yang maknanya berlainan (15 makna) di berbagai konteks penggunaannya dalam Alquran (wujüh). ${ }^{61}$ Fitnah bisa bermakna shirk (syirik). Jika makna ini dipilih, sebagaimana dirujuk oleh Imam Samudera dari penafsiran Ibn Kathir, ${ }^{62}$ itu artinya bahwa perang bersifat ofensif, karena tujuannya adalah menghapuskan shirk. Jika persoalan perintah perang dipahami dari rasionalisasi begini, perang tidak tergantung lagi dari kenyataan apakah non-Muslim melakukan penindasan, ancaman, dsb. yang menjadi alasan sesungguhnya regulasi perang. Fitnah, dengan merujuk ke beberapa penafsiran, adalah "penindasan" (oppression).

Dari sini, bisa dipahami bahwa perang bertujuan agar tidak ada lagi penindasan dan agama Islam tersebar secara alami. Dari karakter defensif perang yang diijinkan, bisa ditarik pemahaman bahwa nilai yang mendasarinya adalah hukum timbal-balik (resiprocity, mu'awadab) karena perang dibolehkan hanya jika suatu komunitas diperangi, terancam diperangi, keadaan tertindas, dan semaknanya. Itu artinya

${ }^{61}$ Lihat al-Suyūtị, Al-Itqān, vol. 1, 143; Al-Rāghib al-Aṣfihāni, Al-Mufradāt $\bar{f}$ Gharì al-Qur'an (Kairo: al-Maktabah al-Tawfiqiyah, 2003), 373-375; Abdulkader Tayob, "An Analytical Survey of al-Tabari`s Exegesis of the Cultural Symbolic Construct of Fitna", dalam Approaches to the Qur'an, ed. G.R. Hawting \& Abdul-Kader A Shareef (London dan New York: Routledge, 1993), 157-172. Penafsiran kata fitnah dengan shirk pada QS. al-Baqarah [2]: 193, seperti diajukan oleh beberapa penafsir, termasuk Ibn Kathir dan al-Suyūtị, agaknya bertolak dari "korelasi dalam ayat" (munasabah $\overline{f i}$ al-ayab), karena konteksnya perang terhadap orang musyrik. Analisis korelasi adalah media rasional yang hingga batas tertentu boleh dipertanyakan, karena seharusnya sejumlah ayat yang berisi perintah perang dirujuk untuk dipahami ratio legis perintah tersebut, melalui riwayat-riwayat asbāb al-nuzūl dan sejarah yang memaparkan betapa kaum Muslim ditindas dan perjanjian damai dilanggar. Ayat pertama turun tentang kebolehan perang juga memuat alasan, "karena mereka (yang diperangi, kaum Muslim) telah dianiaya" (QS. al-Hajj [22]: 39). Jika riwayat asbāb alnu₹ū harus berinteraksi dengan munasabah ayat, dalam hal ini, seharusnya juga sebaliknya. "Fitnah" adalah "suatu situasi di mana seseorang mendapatkan tekanan dari orang lain, terutama keluarga dan sababat, untuk meninggalkan afiliasinya atau untuk meninggalkan keyakinannya”. Dalam situasi itu, ada unsur, bahwa meski korbannya individu atau keluarga tertentu, tekanan yang dilakukan secara besar-besaran yang menyebabkan korban tidak tahu apa yang harus ia lakukan, sehingga secara lambat laun, ia menyerah kepada penekan, atau menyerah kepada diri sendiri. Lihat Rahman, Major Themes, 159.

62 Lihat http://www.tempointeraktif.com/hg/narasi/2004/09/10.nrs,2004091008,id.html. Diakses pada 14 September 2004; Ibn Kathir, Tafsir al-Qur'an, vol. 2, 336-337. 
bahwa jika pihak yang memerangi berhenti memusuhi, perang harus dihentikan, karena perang adalah tawaran atau paling jauh "kewajiban sebagai sarana (fardìyat al-wasä'il)", ${ }^{33}$ bukan "kewajiban sebagai tujuan (fardịyat al-maqāisid)", dalam istilah al-Zarkashi. Hukum timbal-balik mendasari, bahkan "dasar bagi dasar-dasar" (așl al-usūi $)^{64}$ ditetapkannya hukum lain, yang berkaitan dengan hak untuk hidup, rasa aman, bebas dari ancaman, dan hak memeluk agama. Alasan tersebut terkadang dijelaskan dalam ayat yang sedang dibahas, atau dalam ayat-ayat lain yang setopik, sehingga kesatuan nilai (wihdat alqimab) harus dipahami juga dalam konteks kesatuan topik (wihdat almaw $\left.\bar{u}^{-}\right)^{65}$ dan kesatuan historis (al-wiḩdah al-tarikbiyab). ${ }^{66}$ Hal itu karena ketiga hal ini saling terkait, misalnya, asbāb al-nuгū harus berinteraksi dengan munāsabah (keterkaitan) ayat. ${ }^{67}$

Sepanjang pengetahuan penulis, dan juga penelitian-penelitian yang telah dilakukan, ayat-ayat perang seperti itu, meski turun dalam kurun berbeda, tidak pernah meninggalkan prinsipnya, yaitu hukum timbal-balik yang mendasari perang defensif. Uraian tentang bagaimana semua ayat perang lain terkait diteliti dalam kesatuan topik (al-wihidah al-mawdüiyah), kesatuan historis (al-wiḩdah al-tarikbiyah), dan kesatuan nilai (wihdat al-qimah) akan dikemukakan dalam tulisan lain.

\section{Universalitas Sebagai “Multi-Aspek Kandungan Alquran” dan Keniscayaan Pendekatan Interdisipliner}

Sisi lain dari "universalitas" adalah multi-aspek kandungan (shumūiyah) Alquran. Sebagai "dokumen untuk manusia", tidak

${ }^{63}$ Salah satu kaidah menyatakan "Sesuatu yang tanpanya tidak akan sempurna kewajiban, hukumnya menjadi wajib juga" (mà là yatimm al-wäjib illa bibi, fa huwa wäib).

${ }^{64}$ Thāhā menyebut hukum timbal-balik sebagai "ketentuan yang mempertemukan antara keinginan individu akan kebebasan pribadinya secara mutlak dengan kebutuhan masyarakat akan keadilan sosial yang merata". Thāhā, The Second Message, 132-133.

${ }^{65}$ Tentang hal ini, lihat, misalnya Mustansir Mir, Coherence in the Qur'an: A Study of Islähi's Concept of Nazm in Tadabbur-i Qur'an (USA: American Trust Publications, 1986). Lihat juga Aḥmad b. Muhammad al-Sharqāwi, "Naẓariyat al-Wihdah al-

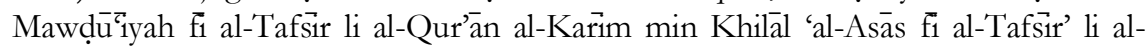
Shaykh Sa đ̄id Hawā' Rahimahullāh," Tesis, Universitas al-Azhar, 1425 H).

${ }^{66}$ Lihat 'Imrān Samị Nazāl, Al-Wị̧dah al-Tarikhìyah li al-Suwar al-Qur'anìyah (Suriah:

Dār Qutaybah dan Amman: Dār al-Qurrā', 2006).

${ }^{67}$ Nazāl, Al-Wị̣dah al-Tärikhìyah, 89-96; Abū Zayd, Mafhūm al-Nașs, 167-175. 
berlebihan jika dikatakan bahwa Alquran memuat aspek-aspek kehidupan manusia, dari doktrin keagamaan (teologi, fikih, dan moral) hingga fakta di dunia fisik dan sosial. Di samping itu, dari segi semantik, Alquran adalah bak intan yang masing-masing sudut memancarkan kemilau yang bisa dilihat oleh seorang penafsir dan tidak selalu dapat dilihat oleh penafsir lain. 'Abdullāh Dirāz, dalam alNaba' al-'Az̧im, menulis sebagai berikut:

"Apabila Anda membaca Alquran, maknanya akan jelas di hadapan Anda. Tetapi, bila Anda membacanya sekali lagi, akan Anda temukan pula makna-makna lain yang berbeda dengan makna-makna sebelumnya. Demikian seterusnya, sampai-sampai Anda (dapat) menemukan kalimat atau kata yang mempunyai arti bermacam-macam, semuanya benar atau mungkin benar. (Ayatayat Alquran) bagaikan intan; setiap sudutnya memancarkan cahaya yang berbeda dengan apa yang terpancar dari sudut-sudut lain. Dan tidak mustahil, jika Anda mempersilakan orang lain memandangnya, maka ia akan melihat lebih banyak ketimbang apa yang Anda lihat." 68

Multi-aspek kandungan Alquran dan keragaman makna, "baik bergerak dari "pesan" ke "kesan" yang muncul, ditopang dari ungkapan yang multi-tafsir, seperti fenomena polisemi (wujüb) dan makna ambigu (mushtarak) dalam Alquran. Dari keragaman makna tersebut, setiap penafsir dengan latar belakang keahliannya, baik sebagai ahli teologi, fikih, tasawuf, saintis, sosiolog, sejarawan, filosof, atau filolog, mendalami makna ayat dari sudut pandangnya.

Jika Alquran dipahami dalam hal kandungannya yang multiaspek, sejatinya, pendekatan yang diterapkan juga interdisipliner atau multi-disipliner. Alquran didekati tidak hanya didekati dari perspektif 'ulum al-Qur'an sekarang, melainkan juga dari perspektif ilmu sosial dan humaniora, seperti sosiologi, antropologi, sejarah, filsafat, dan lingustik. ${ }^{69} \mathrm{Hal}$ ini tidak berlebihan, karena dengan menerapkan ilmuilmu sosial dan humaniora, kajian-kajian tafsir akan lebih kaya dan akan membuka wacana dan perspektif baru. Fazlur Rahman, dengan catatan kritisnya terhadap ilmu sosial lama, menganjurkan kajian Islam

68 Sebagaimana dikutip M. Quraish Shihab, Membumikan al-Qur'an, 16.

${ }^{69}$ Merujuk pandangan Ibrahim Abu Rabi', sebagai bagian dari studi Islam, Studi Alquran harus didekati setidaknya dari empat aspek; filosofis atau ideologis, teologis, aspek teks, dan aspek realitas antropologis. Keempat aspek ini tidak boleh absen dalam kajian terhadap Islam, terutama Alquran. Lihat: Hasan Mahfudh, "Dari Ibrahim M. Abu Rabi' tentang Problematika Studi Islam Kontemporer", dalam Millati: Journal of Islamic Studies and Humanities, vol. 1, no. 1, (2016), 35-36. 
menerapkan "kajian sosial yang lebih baru" (newer social scientific). ${ }^{70}$ Dalam bukunya, Min al-Naql ilā al-'Aql, Hasan Hanafi juga menganjurkan agar 'ulum al-Qur'an bergerak dari ilmu lughah dan balaghah ke humaniora (al-ulum al-insaniyah). ${ }^{71}$ Mohammed Arkoun, tentu saja, termasuk penganjur pendekatan semiotika dan linguistik dalam memahami Alquran, seperti yang pernah diterapkannya dalam memahami QS. al-Tawbah [9]: 5 (dikenal sebagai “ayat pedang”, ayat al-sayff. ${ }^{72}$ Banyak lagi tokoh-tokoh yang juga menganjurkan pendekatan-pendekatan serupa dalam kajian Alquran. Itu artinya, hermeneutika yang selama ini diperdebatkan "halal-haramnya" untuk diterapkan dalam kajian Alquran dicoba untuk dihidangkan di perkuliahan, diletakkan di atas "mizan", diapresiasi, dievaluasi, dan dinilai sejauh mana kelebihan dan kekurangannya; dibiarkan dikompetensikan dengan metode-metode konvensional, sehingga akan terseleksi dengan sendirinya.

Sebagai contoh, dalam kajian antropologi dan komunikasi, analisis wacana (discourse analysis) mungkin diterapkan untuk mengkaji produk tafsir atau penafsiran seorang mufassir. Tafsir sebagai "wacana" dilihat sebagai representasi konteks lebih luas yang melahirkan tafsir tersebut, baik konteks sosial, budaya, politik, ideologi, dan sebagainya. Tafsir yang bias-gender bisa jadi lahir dari konteks pengarang yang diliputi oleh konteks sosial, budaya, politik, dan kepentingan ideologis di masanya. Dengan analisis wacana, tafsir dilucuti kepentingankepentingan ideologis di belakangnya, karena kita memerlukan

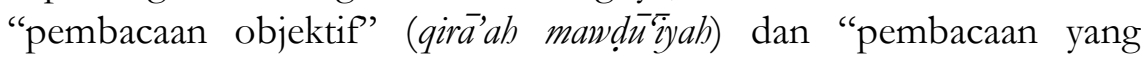
produktif" (qirā'ah muntijah) dalam istilah Abū Zayd.

Di antara jenis analisis wacana adalah analisis wacana kritis model Teun A. Van Dijk, yaitu "suatu tipe kajian analitis terhadap wacana yang terutama difokuskan mengkaji bagaimana penyimpangan kekuatan sosial, dominasi, dan ketidakadilan diciptakan, direproduksi, dan dipertahankan oleh teks dan percakapan dalam konteks sosial dan politik". Penafsiran dalam konteks ini bisa dilihat sebagai wacana

\footnotetext{
${ }^{70}$ Fazlur Rahman, "Approaches to Islam in Religious Studies, Review Essay," dalam Approaches to Islam in Religious Studies, ed. Richard C. Martin (Tucson: The University of Arizona Press, 1985), 201.

${ }^{71}$ Hasan Hanafi, Min al-Naql ilā al-'Aql (Juz 1): 'Ulum al-Qur'an (Min al-Maḅmūl ilā alHämil (Kairo: Dār al-Amir, 2009), 15.

${ }^{72}$ Mohammed Arkoun, Al-Fikr al-Islamì Qiräah Tlmìyah (Beirut: Markaz al-Inmā' alQawmi, 1987), 93-99.
} 
dengan pendekatan kognisi sosial (socio-cognitive approach). Ada keterkaitan tiga hal dalam analisis wacana ini, yaitu "segitiga wacanakognisi-masyarakat" (discourse-cognition-society triangle). Kognisi sosial bisa berupa rasisme atau bentuk ketidakadilan. Dalam hal ini, ideologi dianggap sebagai sesuatu yang disadari. ${ }^{73}$

Pendekatan ini menyediakan cara kerja yang lebih operasional dan rinci dalam kajian kritis terhadap tafsir yang, saya kira, tidak diterapkan oleh pengkaji-pengkaji tafsir semisal Muhammad Husayn al-Dhahabi dalam disertasinya yang kemudian diterbitkan sebagai $\mathrm{Al}$ Tafsì wa al-Mufassirün, meski ia juga berbicara tentang aliran-aliran dan ideologi-ideologi tafsir. Pendekatan ini relevan untuk membongkar ketidakadilan yang bermuara dari pemahaman yang keliru terhadap ayat-ayat Alquran, seperti tafsir-tafsir yang bias-gender dan tafsir-tafsir eksklusif dalam memandang keberadaan komunitas berbeda. Meskipun demikian, sebagai sebuah pendekatan, kita juga harus melihatnya secara objektif dengan menyadari bahwa ada kelemahan tertentu di samping keunggulannya, seperti pada analisis wacana. ${ }^{74}$ Tawaran metode "pembacaan" turath model al-Jabiri, misalnya, mungkin lebih bisa "berlaku adil" terhadap khazanah intelektual tafsir dan bisa menutupi sebagian kelemahan itu. Dalam kerangka metode pengkajian al-Jābirī, tafsir bisa dipahami melalui "logika" masa ketika tafsir itu dilahirkan atau masuk ke dunia penafsir (wasl al-qāri' bi almaqri') maupun mengambil jarak antara produk tafsir yang dibaca itu dengan dunia baru pengkaji (faşl al-qäri' 'an al-maqrü'). ${ }^{75}$

\section{Kesimpulan}

Tafsir integratif, melalui pendekatan interdisipliner dan multidisipliner, merupakan suatu keniscayaan, karena Alquran sebagai petunjuk bagi manusia bersifat universal, baik dalam pengertian

73 Teun A. Van Dijk, "Multidisciplinary CDA: A Plea for Diversity," dalam Methods of Critical Discourse Analysis, ed. Ruth Wodak dan Michael Meyer (London: Sage Publication, 2001), 97-98.

74 Marianne Jorgensen dan Louise J. Phillips, Discourse Analysis as Theory and Method (London: Sage Publication, 2002), 102.

${ }^{75}$ Muhammad 'Ābed al-Jābiri, Nahn wa al-Turāth: Qirā'ab Mu'ạsirah fī Turāthinā alFalsafī (Beirut: al-Markaz al-Thaqā̄i al-'Arabi, 1986), 21-23, 47-49. Lihat: Hasan Mahfudh, "Dari 'Ābid al-Jābirīi tentang Epistemologi Arab Islam," dalam Dialogia: Jurnal Studi Islam dan Sosial, vol. 13, no.1 (2016), 4-5. Bandingkan: Wardatun Nadhiroh, "Fahm Al-Qur'an Al-Hakim; Tafsir Kronologis Ala Muhammad Abid Al-Jabiri," dalam Jurnal Ilmiah Ilmu Ushuluddin, vol. 15, no. 1 (2017), 13-24. 
pesannya yang abadi dan lintas ruang-waktu maupun dalam pengertian multi-aspek kandungan Alquran. Pesannya yang abadi tentu saja bermakna bahwa ada nilai-nilai permanen dan fundamental yang bisa bertahan dan relevan dalam berbagai konteks masyarakat. Oleh karena itu, kita perlu membedakan antara ayat yang partikular dan ayat yang universal. Ayat-ayat universal itu, antara lain, berkaitan dengan fondasi teologis dan moral yang tidak mungkin luntur dengan pergantian waktu dan tempat. Pendekatan dalam memahami ayat tidak cukup hanya legalistik-formal yang terpaku pada status hukum, melainkan dengan mencoba tujuan ideal-moralnya secara lebih mendalam. Untuk membuka sisi universalitas pesan Alquran ini, perlu pendekatan beragam.

Alasan mendasar lain bagi perlunya pendekatan tafsir secara integratif adalah multi-aspek kandungan Alquran. Pesan Alquran membentang dari pesan teologis, legal, moral hingga pembuktian saintifik, sehingga pendekatan yang diterapkan juga kaya nuansa dan beragam perspektif; teologis, fikih, sufistik, sosiologis, antropologis, maupun historis. Pendekatan apa pun yang diterapkan dalam menafsirkan Alquran sebaiknya tetap memperhatikan tiga kesatuan, baik secara tematis, historis, maupun etis (nilai).

\section{Daftar Pustaka}

'Ali, Muhammad Kurdi. Rasa'il al-Bulaghà'. Cairo: Mușțafà al-Bābi alHalabi, 1913.

'Alwānì (al), Tāhā Jābir. Naḥw al-Tajdìd wa al-Ijtibàd. Kairo: Dār Tanwir, 2008.

'Āṣi, Muhạmmad Sālim Abū. Asbāb al-Nuðūil: Tạ̣dìd Mafăbìm wa Radd Shubhāt. Kairo: Dār al-Bașā'ir, 1996.

'Āshūr (ibn), Muhammad al-Ṭăhir. Al-Taḥirir wa al-Tanwìr. Tunis: Dār Suhnün li al-Nashr wa al-Tawzi', 1997.

Maqăsid al-Sharīah al-Islämìyah. Tunis: Dār Suhnūn dan Kairo: Dār al-Salām, 2008.

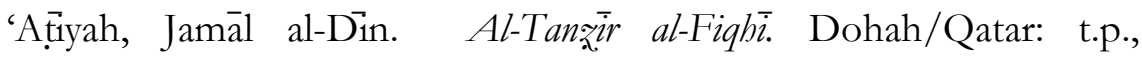
$1407 / 1987$.

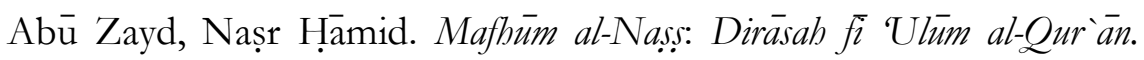
Maroko: al-Markaz al-Thaqā̄i al-'Arabi, 2005.

Ahmad, Nadzrah, and Ahmad Nabil B. Amir. "Muhammad Asad's the Message of the Qur'an." Sociology and Anthropology, vol. 4, no. 12 (2016). 
Ālūsì (al), Shihāb al-Dīn. Sufrat al-Zād li Safarat al-Jihäd, 6-7 manuskrip (MS) dalam www.mostafa.com.

Arkoun, Mohammed. Al-Fiker al-Islämì: Qiräah Tlmìyah. Beirut: Markaz al-Inmä' al-Qawmi, 1987.

Asad, Muhammad. The Message of the Qur'an. Gibraltar: Dār al-Andalus, 1980.

Aṣfihāni (al), al-Rāghib. Al-Mufradāt fì Gharìb al-Qur'ān. Kairo: alMaktabah al-Tawfiqiyah, 2003.

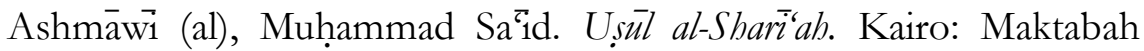
Madbūīi dan Beirut: Dār Iqrā', 1983.

Aziz, Muhammad. "Reconstruction of Maqashid Shari'ah Perspective Muhammad Thahir Ibn 'Assyria: Efforts to Re-Discuss Sharia with Reality." Jurnal Hukum Islam, vol. 12, no. 2 (2019).

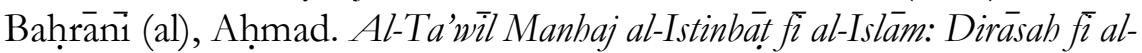
Tarikh wa al-Turath wa al-Fiker Takshif 'an Ma'álim Manhaj alIstinbät ind al-Rasūl wa Abl al-Bayt wa al-Ṣahäbah. t.tp.: Dār alTa'wil, 1999.

Baso, Ahmad. Islam Pasa-Kolonial. Bandung: Mizan, 2005.

Christmann, Andreas. "The Form is Permanent, But the Content Moves: the Qur'anic Text ad Its Interpretation(s) in Mohamad Shahrour's al-Kitāb wa al-Qur'an"." Modern Muslim Intellectual and the Qur'an. Diedit oleh Suha Taji-Farouki. London: The Institute of Ismaili Studies, 2004.

Chudlori, M. Zayin. "Gagasan Mahmud Muhammad Taha tentang Evolusi Syariah." Al-Qanun: Jurnal Pemikiran dan Pembaharuan Hukum Islam, vol. 11, no. 1 (2008).

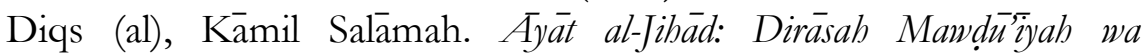
Tarikhiyah wa Bayāìjah. Kuwait: Dār al-Bayān, 1392/1972.

Esack, Farid. Qur'an, Liberalism, and Pluralism: An Islamic Perspective of Interreligious Solidarity Against Oppression. Oxford: Oneworld, 1997.

Fathullah, Roji. "Pemikiran Pembaharuan Hukum Islam Mahmud Muhammad Thaha." Tarkiya, vol. 18, no. 1 (2017).

Fuad, Moh Fahimul. "Asy-Syatibi dan Konsep Istiqra' Ma'nawi." AsSalam: Jurnal Studi Hukum Islam \& Pendidikan, vol. 1, no. 1 (2012). 
- "Maqāasid al-Syari'ah dalam Ayat-ayat Makkiyyah: Study Pemikiran Asy-Syatibi." IN RIGHT: Jurnal Agama dan Hak Azazi Manusia, vol. 3, no. 1 (2017)

Hādi (al), Al-Sayyid 'Abd. Hādhih Ummatukum. Kairo: Dār al-Fikr al'Arabi, 1992.

Hạakim (al). Al-Mustadrak 'ala al-Ṣahīhayn. Diedit oleh Muștafá 'Abd alQādir 'Atạ'. Beirut: Dār al-Kutub al-'Ilmìyah, 1990.

Hanafî, Hạan. Min al-Naql ilā al-'Aql (Juz 1): 'Ulüm al-Qur'ān (Min alMahmūi ilā al-Hạmil. Kairo: Dār al-Amir, 2009.

Hasan, Moh Abdul Kholiq. "Ayat-ayat Kebebasan Beragama dalam Perspektif Nasakh: Kajian Terhadap Penafsiran Ibn Kathir dan Rashid Rida." Mutawatir Jurnal Keilmuan Tafsir Hadith, vol. 6, no. 2 (2016).

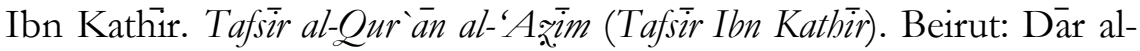
Fikr, 1986.

Jawzìyah (al), Ibn Qayyim. I läm al-Muwaqqi $\overline{i n}$. Kairo: Dār al-Hadith, 2004.

Jābirī (al), Muḥammad 'Ābid. Naḥn wa al-Turāth: Qira'ah Mu'așirah fī Turäthinā al-Falsafî. Beirut: al-Markaz al-Thaqāfi al-'Arabi, 1986.

Jorgensen, Marianne dan Louise J. Phillips. Discourse Analysis as Theory and Method. London: Sage Publication, 2002.

Kusmana. "Epistemologi Tafsir Maqasidi." Mutawatir Jurnal Keilmuan Tafsir Hadith, vol. 6, no. 2 (2016).

Ma'rifah, Muhammad Hādi. Sejarah al-Qur'an, diterjemahkan oleh Thoha Musawa. Jakarta: al-Huda, 2007.

Madjid, Nurcholish. "Kalam Kekhalifahan dan Reformasi Bumi (Suatu Percobaan Pendekatan Sistematis terhadap Konsep Antropologis Islam)". Pidato pengukuhan guru besar luar biasa dalam falsafah dan kalam, IAIN Syarif Hidayatullah, Jakarta, 1419/1998.

Mahfudh, Hasan. "Dari 'Ābid al-Jābirì tentang Epistemologi Arab Islam," Dialogia: Jurnal Studi Islam dan Sosial. vol 13. no.1 (2016).

, Hasan. 'Dari Ibrahim M. Abu Rabi' tentang Problematika Studi Islam Kontemporer". Millati: Journal of Islamic Studies and Humanities. vol. 1. no. 1. (2016). 
Mir, Mustansir. Coherence in the Qur'an: A Study of Islähi's Concept of Narm in Tadabbur-i Qur'an. USA: American Trust Publications, 1986.

Mubārak (al), 'Abdullāh b.. Kitāb al-jihāed, ed. Nazìh Ḥammād. Jaddah: Dār al-Matbứat al-Hadithah, t.th.

Muzaffar, Chandra. "Universalism in Islam." Liberal Islam: A Sourcebook. Diedit oleh Charles Kurzman. Oxford: Oxford University Press, 1998.

Nadhiroh, Wardatun. "Fahm Al-Qur'an Al-Hakim; Tafsir Kronologis Ala Muhammad Abid Al-Jabiri," Jurnal Ilmiah Ilmu Ushuluddin 15, no. 1 (2017).

Nadia, Zunly. "Membaca Ayat Poligami Bersama Fazlur Rahman." Mukaddimah: Jurnal Studi Islam, vol. 2, no. 2 (2018).

Naim (al), Abdullah Ahmed. Toward an Islamic Reformation: Civil Liberties, Human Rights, and International Law. Syracuse, New York: Syracuse University Press, 1996.

Nazāl, 'Imrān Samihị. Al-Wiḅdah al-Tärikbìyah li al-Suwar al-Qur'anìyah. Suriah: Dār Qutaybah dan Aman: Dār al-Qurrā', 2006.

Rahman, Fazlur. "Islam: Challenges and Opportunities." Islam: Past Influence and Present Challenge. Diedit oleh Alford T. Welch dan Pierre Cachia. Edinburgh: Edinburgh University Press, 1979. . "Social Change and Early Sunnah." Hadith and Sunnab: Ideals and Realities. Diedit oleh P.K. Koya. Kuala Lumpur: Islamic Book Trust, 1996.

. "Approaches to Islam in Religious Studies, Review Essay." Approaches to Islam in Religious Studies. Diedit oleh Richard C. Martin. Tucson: The University of Arizona Press, 1985. . Islam and Modernity, Transformation of an Intellectual Tradition. Chicago: The University of Chicago, 1982. . Islam dan Modernitas, diterjemahkan oleh Ahsin Mohammad. Bandung: Pustaka, 1995. - Major Themes of the Qur'an. Kuala Lumpur: Islamic Book Trust, 1989.

Sabt (al), Khālid b. 'Uthmān. Qawàid al-Tafsìr. Jam'an wa Diräsatan. Giza, Mesir: Dār Ibn 'Affān, $1421 \mathrm{H}$.

Sa'dì (al), 'Abd al-Raḥmān. Al-Qawā'id al-Hisā̄n. t.tp.: Dār Ibn al-Jawzì, t.th.

Shihab, M. Quraish. "Membumikan” al-Qur`an. Bandung: Mizan, 1995. 
Suyūți (al), Jalāl al-Dīn. Al-Itqān fī 'Ulum al-Qur'an. Beirut: Dār al-Fikr, t.th.

- Al-Taḅbir fi $\bar{i}$ Tlm al-Tafsir. Beirut: Dār al-Kutub al-'Ilmiyah, 1988.

Sharqāwi (al), Aḥmad b. Muḥammad. "Naẓariyat al-Wiḥdah alMawḍūí̄iyah fi al-Tafsir li al-Qur'ān al-Karim min Khilāl 'alAsās $\overline{\mathrm{fi}}$ al-Tafsir' li al-Shaykh Sa’̄id Hawā' Rahimahullāh.” Tesis, Universitas al-Azhar, $1425 \mathrm{H}$.

Shātibīi (al), Abū Isḥāq. Al-Muwā́faqāt. Diedit oleh 'Abdullāh Dirāz. Beirut: Dār al-Kutub al-'Ilmiyah, t.th.

Tayob, Abdulkader. "An Analytical Survey of al-Tabari's Exegesis of the Cultural Symbolic Construct of Fitna." Approaches to the Qur'an. Diedit oleh ed. G.R. Hawting \& Abdul-Kader A Shareef. London dan New York: Routledge, 1993.

Ṭăhā, Maḥmūd Muhammad. Al-Qur'ān wa Muștafā Mahmūd wa al-Fahm al-'Asri, dalam www.alfikra.org.

Al-Risālah al-Thäniyah min al-Isläm, dalam www.alfikra.org/htm.

. The Second Message of Islam, diterjemahkan oleh Abdullahi Ahmed an-Naim. Syracuse, New York: Syracuse University Press, 1987.

Ulya, Ulya. "Hermeneutika Double movement Fazlur Rahman: Menuju Penetapan Hukum Bervisi Etis." ULUL ALBAB Jurnal Studi Islam, vol. 12, no. 2 (2013).

Ulyati, Fahmi. "Pemikiran Fazlur Rahman Dalam Q.S. An-Nisā' [4]: 3 Tentang Poligami." SY ARIATI, vol. 3, no. 01 (2017).

Van Dijk, Teun A. "Multidisciplinary CDA: A Plea for Diversity," dalam Methods of Critical Discourse Analysis. Diedit oleh Ruth Wodak dan Michael Meyer. London: Sage Publication, 2001.

Wardani. Islam Ramah Lingkungan: dari Eko-teologi al-Qur'an hingga Figh al-Bi'ah. Banjarmasin: IAIN Antasari Press, 2015.

Yübi (al), Muhammad Sa‘d b. Ahmmad b. Mas‘ùud. Maqāsid al-Shari’ah alIslämiyah wa 'Aläqatubà bi al-Adillah al-Sbar'îyah. Makkah: Dār al-Hijrah li al-Nashr wa al-Tawzi', 1418/1998.

Zarkashi (al), Badr al-Dīn. Al-Burbān fì 'Ulüm al-Qur'an. Beirut: Dār alFikr, 2001. 